\title{
Vitamins, Amino Acids, Lipids and Sterols of Eggs from Three Different Birds Genotypes
}

\author{
O.Aletor $^{1}$ and F.M Famakin ${ }^{2}$ \\ ${ }^{1,2}$ Department of Chemistry, The Federal University of Technology,P.M.B.704,Akure Nigeria
}

\begin{abstract}
The study compared the nutritional and physical quality of whole raw and cooked eggs of birds collected from three different genotypes as well as environments,namely (Broiler chicken (Gallus gallus), quail (Coturnix coturnix japonica) and Local chicken or indigenous (Gallus gallus domesticus). The eggs were divided into two portions one portion was cooked for 30 minutes. Furthermore the whole boiled and cooked of these eggs were characterized with respect to their vitamins and amino acids and the oils extracted from them were analyzed for individual fatty acid and sterols. Among all the vitamins analyzed for vitamin B5 that was highest and ranged $1.409 \mathrm{mg} / 100 \mathrm{~g}$ in raw boiler eggs to I.529mg/100g in boiled quail eggs. Amino acid profile compared well among all the eggs analyzed for with minimal differences in their concentrations. However, among all the amino acid, glutamate had highest concentration ranged 13.81-14.94g/100g protein and the least concentrated was tryptophan and ranged 0.66-0.82g/100g protein. The saturated fatty acids (SFA) were (in \% of total fatty acid) had the best level $46.888 \mathrm{mg} / \mathrm{l00} \mathrm{g}$ in raw quail egg and the lowest level of 4 l.813mg/l00g was found in raw broiler egg. MUFA was highest in raw local chicken egg 43.267g/.The range in PUFA, AA/DGLA, EPA/PHA LA/ALA, $n-6 / n-3$, PUFA/SFA MUFA/SFA and EPSI were 12.034- 20.474, 0.219-0.506; 0.015- 0.615; 2436.4-9683.0; 7.670-14.574; $0.883-0.993$ and $0.291-0.0 .552 \mathrm{~g} / \mathrm{l00g}$ respectively. The only sterol of significance was cholesterol with a range of $269.9-357.2 \mathrm{mg} / 100 \mathrm{~g}$.The study indicated that the thre different eggs analyzed contained high nutritional contents of vitamins, amino acids, fatty acids and sterols irrespective of the environment however, heat had effect on the nutrients especially the vitamins.
\end{abstract}

Keywords: eggs, amino acids, fattyacid, sterols, vitamins

\section{Introduction}

A balanced and digestible diet is essential for proper growth of human body [1]. Over the years man has made avian eggs as one of the major source of food intake. This is because it is a versatile source of food for man which is believed to possess high animal protein content besides milk, and other vital nutrient such as amino acid ,easily digestible fats , minerals as well as vitamins[2]. The yolk and egg white components are all of high biological value and are readily digestible.

There are many types of birds eggs that are consumed as good source of protein and other nutrient supplement [3]. Some birds are found in the wild while some are domesticated, the question arises whether the environmental differences in egg production by these birds affect the nutritive value and quality of the eggs. Some of these laying birds are reared domestically e.g broiler chicken (Gallus gallus domesticus ), local, traditional or indigenous chicken (Gallus gallus ) and example of the wild is quail (Courtunix cortunix) .Broiler chicken are hybrid of egg laying chicken and a sub specie of the red jungle fowl, they are raised specifically for meat production and they are bigger than the local chicken, it reaches maturity to lay eggs weather fertilized or not from 20 weeks. The local indigenous chickens are widely distributed in the rural areas of tropical and subtropical countries. They do well in harsh climatic conditions and most reared free range. The growth rate and egg production under convectional system of rearing are very low ,about 40 eggs/yr [4]. Quail birds (Courtunix courtnix) is small rotund bird. They build nest and lay their eggs. in tall grasses of the plains and farmlands. Nowadays some are raised in the poultry instead of tall grasses, by nature quail are very wild and when domesticated, they are restless and anxious [5].

Eggs are consumed in both raw and processed states such as fried, cooked and poached. Recently, in Nigeria a lot of attention has been drawn to quail eggs [1]. Some even suggested that it was better to swallow the whole raw eggs including the shells for maximum utilization of the health benefits by the body system .However, scientific data are hardly available on the nutritional qualities of processed and raw eggs from domesticated fowls as well as those eggs from the wild.Thus this study aimed to evaluate the nutritional compositions of vitamins, amino acid ,fatty acid profile as well sterols contents of three different avian eggs This idea may resolve the world food problem for developing countries Nigeria inclusive. 


\subsection{Sample Collection}

\section{Materials and Methods}

The broiler eggs were obtained from chickens breed under controlled condition and the local Chicken eggs were obtained from free ranged local birds source in Akure, Ondo-State, while the quail eggs were collected from a farmland also in Akure .All the eggs were collected between may and July 2015.

\subsection{Sample treatment}

The various eggs were washed with distilled water and divided into two sets. A set was boiled for 30 mins at a temperature between $100^{\circ} \mathrm{C}-140^{\circ} \mathrm{C}$, while the second set was treated raw .Each of these set (boiled and raw) were cracked, emptied into previously weighed Petri-dishes and dried in the oven for $8 \mathrm{hr}$ at temperature between $60-70^{\circ} \mathrm{C}$. The dried samples were homogenized by a laboratory blender(Moulinex A327,France), sieved through a mesh size 25 and kept in Freezer $\left(-4^{0} \mathrm{C}\right)$ pending analysis.

\subsection{Extraction of lipid}

$1 \mathrm{~g}$ of each sample was weighed into the extraction thimble. Two hundred $\mathrm{ml}$ of petroleum ether (40$60^{\circ} \mathrm{C}$ boiling range) was measured and then added to the dried $250 \mathrm{ml}$ capacity flask. The covered porous thimble with the sample was placed in the condenser of the soxhlet extractor arrangement that has been assembled [6]. The lipid was extracted for $5 \mathrm{~h}$. The extraction flask with the oil was cooled in the desiccators and the weight of the cooled flask with the dried oil was measured

\subsection{Methods}

2.4.1Vitamins analysis was conducted by saponification and liquid extraction of organic solvents with HPLC Fluorescence detection [7]

\subsubsection{Amino acid profile:}

Amino acids were determined by high performance liquid chromatography (HPLC) by the method of [8]. Finely ground samples were hydrolyzed by adding $4.83 \mathrm{~g}$ Barium hydroxide and $5 \mathrm{ml}$ of boiling water to $500 \mathrm{mg}$ of sample. The mixture was evacuated and then heated at $120^{\circ} \mathrm{C}$ for 8 hours. After hydrolysis, the $\mathrm{pH}$ was adjusted to 3 with $\mathrm{HCl}$, and diluted to $25 \mathrm{ml}$ with HPLC grade distilled water. $1 \mathrm{ml}$ of sample was vacuum dried using flash evaporator and finally dissolved in citrate buffer $(0.1 \mathrm{~m} ; \mathrm{pH} 2.2)$.

Acid hydrolysis is carried out with $6 \mathrm{~N} \mathrm{HCl}$ at $110^{\circ} \mathrm{C}$ to $18-22 \mathrm{hrs}$ in evacuated and sealed tubes. The hydrolysate was filtered and diluted to $250 \mathrm{ml} .1 \mathrm{ml}$ of sample was vacuum evaporated at $40^{\circ} \mathrm{C}$ until dryness. The content was dissolved in citrate buffer $(0.1 \mathrm{M} ; \mathrm{pH} 2.2)$. $20 \mu \mathrm{l}$ of this derivatized were injected directly into the HPLC. Detection was accomplished using Shimadzu HPLC detector LC-10A with variable wavelength monitor set at $350-450 \mathrm{~nm}$. Resolution of amino acid derivatives was routinely accomplished using a binary gradient system.

The solvent used were: (A) $58.8 \mathrm{gm}$ of sodium citrate containing $0.2 \mathrm{~N}$ sodium (pH 3.2), $210 \mathrm{ml} 99.5 \%$ ethanol and $50 \mathrm{ml}(60 \%)$ Perchloric acid and (B) $58.5 \mathrm{gm}$ of sodium citrate containing $0.6 \mathrm{~N}$ sodium (pH 10 ), $12.4 \mathrm{~g}$ Boric acid and $30 \mathrm{ml} 4 \mathrm{~N} \mathrm{NaOH}$ solution. Solvent was delivered to the column at a flow rate of $4 \mathrm{ml} / \mathrm{min}$ for 7 to 10 minutes.

\subsubsection{Preparation of methyl esters and analysis}

Fifty $\mathrm{mg}$ of the extracted oil was saponified for $5 \mathrm{~min}$ at $95^{\circ} \mathrm{C}$ with $3.4 \mathrm{ml}$ of $0.5 \mathrm{M} \mathrm{KOH}$ in dry methanol . The mixture was neutralized by $0.7 \mathrm{M} \mathrm{HCI}$. Three $\mathrm{ml}$ of $14 \%$ boron triflouride in methanol was added [6]. The mixture was heated for $5 \mathrm{~min}$ at $90^{\circ} \mathrm{C}$ to achieve complete methylation process. The methyl esters were trice extracted from the mixture with redistilled $\mathrm{n}$-hexane . The content was concentrated to $1 \mathrm{ml}$ for analysis and $1 \mu \mathrm{L}$ was injected into the injection pot of the GC. The fatty acid methyl esters were analyzed using an HP 5890 powered with HP Chemstation rev.AO9.01 $\{1206\}$ software [GMI.Inc. Minnesota,USA] fitted with a flame ionization detector. Nitrogen was the carrier gas with a flow rate of $20-60 \mathrm{ml} / \mathrm{min}$. The oven program was :initial temperature at $60^{\circ} \mathrm{C}$, first ramping at $10^{\circ} \mathrm{C} / \mathrm{min}$ for $20 \mathrm{~min}$ and maintained for $4 \mathrm{~min}$, second ramping at $15^{\circ} \mathrm{C} / \mathrm{min}$ for $4 \mathrm{~min}$ maintained for $10 \mathrm{~min}$. The injection temperature was $250^{\circ} \mathrm{C}$ whilst the detector temperature was $320^{\circ} \mathrm{C}$. A capillary column $(30 \mathrm{~m} \times 0.25 \mathrm{~mm})$ packed with a polar compound (HP INNOWAX) with a diameter $(0.25 \mu \mathrm{m})$ was used to separate the esters . Split injection type was used having a split ratio of 20:1. The peaks were identified by comparison with standard fatty acid methyl esters.

\subsubsection{Sterol analysis}

Sterol was analyzed as described by [6]. The aliquots of the extracted fat were added to the screw-capped test tubes. The sample was saponified at $95^{\circ} \mathrm{C}$ for $30 \mathrm{~min}$, using $3 \mathrm{ml}$ of $10 \% \mathrm{KOH}$ in ethanol to which $0.20 \mathrm{ml}$ of benzene had been added to ensure miscibility. Deionized water $(3 \mathrm{ml})$ was added in extracting the non- 
saponifiable materials. Three extractions, each with $2 \mathrm{ml}$ hexane were carried out for $1 \mathrm{~h} .30 \mathrm{~min}$ and $30 \mathrm{~min}$ respectively. The hexane was concentrated to $1 \mathrm{ml}$ in the vival for gas chromatographic analysis, $1 \mu \mathrm{l}$ was injected into injector pot of GC. The peaks were identified by comparison with standard sterols. The sterols were analyzed using similar conditions as fatty methyl ester analysis

\subsubsection{Quality assurance}

Standard chromatograms were prepared for amino acid, sterol, and fatty acid methyl esters which were then compared with respective analytical results; calibration curves were prepared for all the standard mixtures and correlation coefficient determined for each,amino acid, fatty acid parameter and same for sterols . Correlation coefficient should be $>0.95$ for the result to be acceptable. It was performed with Hewlett Packard Chemistry (HPCHEM) software (GMI, Inc6511 Bunker Lake Blvd Ramsey, Minnesota, 55303, USA).

\subsubsection{Statistical analysis}

Statistical analysis[9] was carried out to determine coefficient of variation in per cent (CV \%), the mean and standard deviation.

\section{Results and Discussion}

Table 1 presents the result of vitamins A, B1, B2, B5,, B6,B9,D,E and $\mathrm{K}$ of the raw and cooked three different birds eggs. Vitamin A was low in all the eggs analyzed regardless of either raw or cooked and ranged between $0.001 \mathrm{mg} / 100 \mathrm{~g}$ in cooked local chicken eggs to $0.006 \mathrm{mg} / 100 \mathrm{~g}$ in raw broiler eggs, with mean coefficient of variation (CV\%) of 66.67\%. Among the B series of vitamins ,Vit B5 and B6 were highest in all the eggs analyzed and ranged $1.329 \mathrm{mg} / 100 \mathrm{~g}$ to $1.529 \mathrm{mg} / 100 \mathrm{~g}$ and $0.128 \mathrm{mg} / 100 \mathrm{~g}$ to $0.710 \mathrm{mg} / 100 \mathrm{~g}$ respectively. Values of Vit $\mathrm{D}, \mathrm{E}$ and $\mathrm{K}$ in all the eggs were not significantly $\mathrm{P} \leq 0.05$ different with the mean values of $0.504 \mathrm{mg} / 100 \mathrm{~g}, 0.295 \mathrm{mg} / 100 \mathrm{~g}$ and $4.446 \times \mathrm{e}^{4} \mathrm{mg} / 100 \mathrm{~g}$ respectively. The results on Vitamin A content in the present study are similar to those reported by [10] on nutritional values of eggs of birds from three different genotypes .Of all the Vitamins analyzed for, Vitamin B5 followed by Vit B6 and Vitamin D were the most abundant in all the eggs. Vitamin B helps in the breakdown of fats and carbohydrates for energy and critical to manufacture of red blood cells as well as sex and stress related hormones.lts deficiency include fatigue, insomnia and depression [11].Vitamin B6 is involved in the process of making serotonin and nor epinephrine, which are chemical balance that transmit signals in brain and involved in the formation of myelin, a protein layer that forms around nerve cells. The deficiency in adults may cause health problems affecting the nerves, skin and mucous membrane, while in children the central nervous system is affected [12]. Vitamin D sometimes called sunshine vitamin promotes Calcium absorption in the guts and maintains adequate serum calcium and phosphate concentrations to enable normal mineralization of bone deficiency causes bone thinning [13].Comparatively, the vitamin contents of all the eggs analyzed were similar regardless of how and where the birds were raised, however, heat significantly reduced the Vitamins in the cooked eggs.

The amino acid content of the raw and cooked whole eggs from three different birds are given in Table 2.The results revealed that the majority of the essential amino acid namely valine, threonine ,isoleucine, lysine, and histidine in $(\mathrm{g} / 100 \mathrm{~g})$ protein were highest in raw and cooked eggs with values 4.66,4.19; 4.01,3.93; $9.75,8.02 ; 10.51,8.92$; and 3.02,2.72 respectively. Among the non-essential amino acid glutamate was highest with mean value $(14.45 \mathrm{~g} / 100 \mathrm{~g}$ protein). This was in contrast to the previous study which reported that aspartate had highest composition in quail and local eggs [14].Glutamic acid act as an important neutromitter, hence this amino is critical for healthy brain development and function as well as playing important role in the body disposal of excess waste nitrogen in the form of ammonia[15].Among the essential amino acid leucine was highest and ranged 6.63-9.75g/100g protein with mean value $(8.18 \mathrm{~g} / 100 \mathrm{~g}$ protein). Leucine play a unique role in stimulating muscle protein and also increase growth hormones [16]. The mean value of all the amino acid analyzed ranged from $0.73 \mathrm{~g} / 100 \mathrm{~g}$ protein in tryptophan to $14.45 \mathrm{~g} / 100 \mathrm{~g}$ protein in glutamate. Highest variation was found in lysine as indicated by high coefficient of variation (CV) of $41.60 \%$. Total essential amino acid (TEAA) and total non-essential amino acid were highest in raw local eggs $(43.30 \mathrm{~g} / 100 \mathrm{~g}$ protein) and cooked quail eggs $(55.28 \mathrm{~g} / 100 \mathrm{~g}$ protein) respectively. These results are in appropriate agreement with the most recent data reported by $[14,17]$ on cooked layer chicken whole eggs. The changes in the level of amino acid after heat application may be due to breaking of bonds in some proteins that are heat labile. The degree of lability depends on the type of protein, type of solution and the temperature profile [18].

Table 3 depicts the various levels and types of fatty acids in the extracted fats from different egg samples. In all the samples the following fatty acids (FAs) were not detected in eggs fat. C2:0, C3:0,C4:0, C5:0, C6:0, C8:0 and C10:0 while the only saturated fatty acid (SFA) detected were C12:0(Lauric acid), C14:0(myristic acid),C16:0(palmitic acid), C18:0(oleic acid), C20:0(arachidonic acid), C22:0(behenic acid) and C24:0(lignoceric acid).The values of SFA $A_{S}$ in the analyzed oils of the eggs $(41.813-46.888 \mathrm{mg} / 100 \mathrm{~g}$ ) were very spread with CV\% ranged 94.81e- $-18.34 \%$. The MUFA (cis) values had a range of 37.120 - 
43.588mg/100g.Low levels of MUFA(cis) were observed in C16:1(cis-9) 0.539- 1.625g/100g, C20:1(cis-11) $0.010-0.089 \mathrm{mg} / 100 \mathrm{~g}, \mathrm{C} 22: 1$ (cis-13) $0.00-0.018$ and $\mathrm{C} 24: 1$ (cis-15) $1.136 \mathrm{e}^{-7}-8.193 \mathrm{e}-{ }^{7} \mathrm{~g} / 100 \mathrm{~g}$ where as the major sources of MUFA(cis) were C18:1(cis-6) $\quad 21.022-26.597 \mathrm{mg} / 100$ gand $\quad \mathrm{C} 18: 1$ (cis-9) 13.949$18.680 \mathrm{mg} / 100 \mathrm{~g}$. All the MUFA(trans) values were generally low with the overall range of $0.677 \mathrm{e}^{-6}-4.937 \mathrm{e}^{-6}$ $\mathrm{mg} / 100 \mathrm{~g}$. Literature SFAs and MUFA values of some differently treated diet of white leghorn hen eggs as reported by [19] ranged $10.93-66.80 \mathrm{mg} / 100 \mathrm{~g}$ and $10.49-43.80 \mathrm{mg} / 100 \mathrm{~g}$ respectively. The polyunsaturated fatty acid (PUFA) ranged 12.034- $20.439 \mathrm{mg} / 100 \mathrm{~g}$ and was most concentrated in the raw broiler eggs, but greatly reduced by heat. Results on PUFA were lower than those recorded $22.60-65.12 \mathrm{mg} / 100 \mathrm{~g}$ for some differently treated diet of leghorn egg as described by [19]. Results showed increase in most of the cooked egg oils of SFA in broiler eggs while decrease was observed in palmiticacid in quail eggs after heat application. Local hen eggs showed increased in all boiled eggs oils of SFA except Oleic acid where a decrease was observed. This same trend was observed in MUFA and PUFA of oils from various eggs. This observation may be attributed to the fact that during heating of fats different processes take place which include dehydration, decarboxylation, hydrolysis of esters bond, double-bond. conjugation, polymerization, dehydrocyclization, aromatization, dehydrogenation degradation by carbon-carbon cleavage [20]. The results also showed that increase and decrease of these egg oils were in favor of shorter chain saturated and unsaturated acid which may be explained by their greater solubility in water. Current nutritional thinking appears to be that dietary trans monoenoic fatty acids both from animal and from industrial hydrogenation processes should be considered as potentially harmful and in the same light as saturated fatty acid [21].Overall results showed that irrespective of the environmental differences of these birds , little was observed in the SFA, MUFA, and PUFA. However, results showed that raw quail eggs had highest SFA, MUFA was highest in raw local egg chickens while PUFA was highest in raw broiler egg hens. The result showed that all the analyzed eggs had higher fat but most of them were unsaturated fatty acid (UFA) which was better for health, furthermore, all analyzed eggs had low trans fatty acid which was bad for human health. Consuming trans fat increases low-density lipoprotein (LDL, or "'bad") cholesterol. In most developed countries food manufacturers list the trans fat content in nutrition labels. They recommend a limit of less than 0.5 grams of trans fat per- serving [22] ln Table 3 there were important long chain (14-18 carbon atom) and very long chain (20-24 C-atoms). The two essential fatty acid (EFAs) are C18:2 cis $-9,12$ and C18:3 cis-9,12,15. The former was highest among all the PUFA analyzed for in the egg oils and ranged 9.335$16.83 \mathrm{mg} / 100 \mathrm{~g}$ and the latter ranged $0.001-0.003 \mathrm{mg} / 100 \mathrm{~g}$ respectively. Another important long -chain fatty acid is gamma-linolenic acid (GLA) \{C18:3cis 6,9,12\} .lt formed a low level and ranged between 0.014$0.099 \mathrm{mg} / 100 \mathrm{~g}$ in all the samples; it is mostly found in black currant oil [21]. The body makes GLA out of omega-6 linolenic acid and uses it in the production of substances called prostaglandins, a localized tissue hormones that regulates many processes at the cellular level. The level of eicosadienoic acid (C20:2 cis-11,14), eicosatrienoic acid n-6 (C20;3 cis-8,11,14) and eicosatrienoic (n-3) $(\mathrm{C} 20: 3$ all cis-11,14,17) were very low $\left(0.141 \mathrm{e}^{6}-1.018 \mathrm{e}^{-}{ }^{6} ; 1.67 \mathrm{e}^{-}{ }^{6}-12.000 \mathrm{e}^{-}{ }^{6}\right.$ and $\left.0.610 \mathrm{e}-{ }^{6}-4.399 \mathrm{e}-{ }^{6} \mathrm{mg} / 100 \mathrm{~g}\right)$ respectively. It has been suggested that arachidonic acid $(\mathrm{C} 20: 4$ cis-5,8,11,14) which ranged $0.126-1.159 \mathrm{mg} / 100 \mathrm{~g}$ in egg oils under study is detrimental to human health [23]. However, it promotes inflammation that is an important protective response when one is injured. It also forms the basis of anti-inflammatory prostaglandin that the body uses to reduce inflammation (Fallon and Ening,1996). Since all the egg oils analyzed in this study had low level of arachidonic acid (AA) thus, a great amount of eggs have to be consumed to detect any contradictory effect.

Some calculated parameters are shown in Table 4 . They included the SFA, MUFA cis, MUFA total, PUFA and some other ratios in the different raw and cooked egg oils. The AA/DGLA(di-homo-gammalinolenic acid) values were $0.219-0.506 \mathrm{mg} / 100 \mathrm{~g}$. A high ratio between AA and DGLA, is an activity of delta5,desaturase which is required for the synthesis of highly unsaturated fatty acids such as eicosopentaenoic fatty acids which are esterified into phospholipids and contribute to maintaining membrane fluidity [24]. However, the ratio of the present study on egg oils were low when compared to those of $5.73-13.7 \mathrm{mg} / 100 \mathrm{~g}$ found in the oils of three organs of antelope reported by [21]. The EPA/DHA (eicosapentaenoic and docosahexaenoic acid) results ranged $0.015-2.829 \mathrm{mg} / 100 \mathrm{~g}$. A recommended ratio of $2: 1$ or vice versa was suggested in a report given by [25]. Among the different oils analyzed for, oils from raw broiler and quail eggs fell within the range. Both form of Omega 3 have beneficial effects on the stress response and wellbeing of infants in both the short term and well into childhood [26]. The total ratio of omega 6 (n-6) and omega 3 (n-3) ranged $10.827-20.045 \mathrm{mg} / 100 \mathrm{~g}$ and $0.846-1.702 \mathrm{mg} / 100 \mathrm{~g}$ respectively. The raw broiler eggs had highest value in $\mathrm{n}-6$ but drastically reduced after boiling , the reason for the reduction may be adduced to the earlier mentioned heating effects on fats [20]. The results on the total $n-6$ and $n-3$ showed that $n-6$ values were more than 10 times higher than $n-3$. This negates the earlier report by [27] that $n-6$ should be twice as much as $n-3$ in the diet that is at ratio 2:1. [28] suggests that eating omega -6 and omega- 3 in the wrong proportion may actually negate the health benefits. Report by [29] showed that linoleic acid enriches membrane phospholipids and predisposes them to free radical oxidation. When the these fatty acids are eaten in right amounts they are important for systems of the body to function normally, including skin , respiratory system, circulatory system, brain and 
organs. The relative proportion of MUFA/SFA is an important of phospholipids compositions, changes to this ratio have been claimed to have effects on diseases such as cardiovascular, obesity diabetes,neuropath logical conditions and cancer. The present PUFA/SFA varied between $0.257 \mathrm{mg} / 100 \mathrm{~g}$ in raw quail eggs to $0.490 \mathrm{mg} / 100 \mathrm{~g}$ in raw broiler eggs. The results were lower than than those reported by [30] $0.53 \mathrm{mg} / 100 \mathrm{~g}$ and $1.57 \mathrm{mg} / 100 \mathrm{~g}$ on a Seal and Guinea fowl eggs respectively. MUFA/SFA in samples ranged $0.883 \mathrm{mg} / 100 \mathrm{~g}$ to $0.993 \mathrm{mg} / 100 \mathrm{~g}$ with low CV(\%) of 4.5 . The relative amounts of PUFA and SFA in oils is important in nutrition and health. The ratio of PUFA/SFA (P/S ratio) is important in determining the detrimental effects of dietary fats, the higher the ratio the more nutritionally useful the oils. This is because the severity of atherosclerosis is closely associated with the proportional of the total energy supplied by the saturated and polyunsaturated fats [31,21]. One suitable indicator of essential PUFA status index (EPSI), is the ratio between all essential PUFA (the sum of all the n-3 and n-6 FA's) and non-essential unsaturated FA's (the sum of all n-7 and n-9 FA's). The higher the essential PUFA status index the better the better the essential PUFA status [24]. The index was highest in raw broiler chicken eggs $(0.552 \mathrm{mg} / 100 \mathrm{~g})$ and lowest value of $0.291 \mathrm{mg} / 100 \mathrm{~g}$ was found in raw quail eggs . However, the effect of cooking increased the index to $0.420 \mathrm{mg} / 100 \mathrm{~g}$.

In the analysis of zoosterol (Table 5) only cholesterol was detected in all the samples at appreciable levels with values in $(\mathrm{mg} / 100 \mathrm{~g})$.Raw and cooked eggs of broilers quail and local chicken had 269.9; 321.9; $279.2,231.0 ; 357.2,260.0 \mathrm{mg} / 100 \mathrm{~g}$ respectively. Cholesterol is a fatty compound involved in the transport of fat in the blood stream of all animals and is necessary for proper functioning of our cell membranes and production of hormones. Cholesterol is not a dietary essential since adequate amounts are synthesized in the body from other dietary ingredients. The current daily allowance (RDA) of cholesterol is 300mg.[32] The study [32] also advised that we should get less than $200 \mathrm{mg} /$ day, if you have high cholesterol or other risk factor for heart diseases. The results of the present study showed that boiled broiler eggs and raw local chicken eggs are beyond the limit while quail eggs (raw and boiled) are within the limit. The results on quail cholesterol are in agreement with those reported by[5,14]. Other sterols recorded less than $0.5 \mathrm{mg} / 100 \mathrm{~g}$ in all the samples: cholestanol, ergosterol, campesterol, stigmaterol, savaenesterol and sitosterol.

\section{Conclusion}

ln conclusion, the findings of this study showed that the eggs, irrespective of the birds environment showed unequal of all the parameters (vitamins, amino acids, fatty acid and sterols) determined. However, heat application affected some of these parameters especially the vitamins. In all the samples, total non essential amino acids(T.N.E.A) were higher than the total essential amino acids(T.E.A.A).The samples are good sources of omega 3and omega 6 especially the raw local chicken eggs and raw broiler eggs. The unsaturated fatty acids values were correspondingly higher than the saturated fatty acids, which are good for heart functioning. The sterols of significance was cholesterol

Table 1: Vitamin content $(\mathrm{mg} / 100 \mathrm{~g})$ of raw and cooked eggs from three avian species

\begin{tabular}{|c|c|c|c|c|c|c|c|c|c|}
\hline & \multicolumn{2}{|l|}{ Broiler } & \multicolumn{2}{|l|}{ Quail } & \multicolumn{2}{|l|}{ Local } & \multirow[b]{2}{*}{ MEAN } & \multirow[b]{2}{*}{$\mathrm{SD}$} & \multirow[b]{2}{*}{ CV\% } \\
\hline Vitamins & $\mathrm{RE}$ & $\mathrm{BE}$ & RE & $\mathrm{BE}$ & $\mathrm{RE}$ & $\mathrm{BE}$ & & & \\
\hline A & $0.006^{\mathrm{a}}$ & $0.003^{\mathrm{a}}$ & $0.004^{\mathrm{a}}$ & $0.003^{\mathrm{a}}$ & $0.003^{\mathrm{a}}$ & $0.001^{\mathrm{a}}$ & 0.003 & 0.002 & 66.67 \\
\hline B1 & $0.262^{\mathrm{ab}}$ & $0.262^{\mathrm{ab}}$ & $0.235^{\mathrm{ab}}$ & $0.274^{\mathrm{ab}}$ & $0.092^{\mathrm{a}}$ & $0.265^{\mathrm{ab}}$ & 0.23 & 0.06 & 26.09 \\
\hline B2 & $0.305^{\mathrm{a}}$ & $0.531^{\mathrm{ab}}$ & $0.476^{\mathrm{ab}}$ & $0.553^{\mathrm{ab}}$ & 0.421 & 0.539 & 0.47 & 0.09 & 19.15 \\
\hline B3 & $0.090^{\mathrm{a}}$ & $0.112^{\mathrm{a}}$ & $0.097^{\mathrm{a}}$ & $0.122^{\mathrm{a}}$ & $0.090^{\mathrm{a}}$ & $0.119^{\mathrm{a}}$ & 0.105 & 0.02 & 17.39 \\
\hline B5 & $1.409^{\mathrm{a}}$ & $1.474^{\mathrm{a}}$ & $1.329^{\mathrm{a}}$ & $1.529^{\mathrm{a}}$ & $1.472^{\mathrm{a}}$ & $1.510^{\mathrm{a}}$ & 1.537 & 0.23 & 14.96 \\
\hline B6 & 0.632 & $0.691^{\mathrm{b}}$ & $0.650^{\mathrm{b}}$ & $0.738^{\mathrm{ab}}$ & $0.128^{\mathrm{a}}$ & $0.710^{\mathrm{ab}}$ & 0.592 & 0.23 & 38.85 \\
\hline B9 $\left(\mathrm{xe}^{-8}\right)$ & $1.73^{\mathrm{d}}$ & $1.991^{\mathrm{a}}$ & $1.817^{\mathrm{a}}$ & $2.378^{\mathrm{a}}$ & $1.3391^{\mathrm{a}}$ & $2.314^{\mathrm{a}}$ & 1.928 & 0.39 & 20.22 \\
\hline $\mathrm{D}$ & $0.459^{\mathrm{a}}$ & $0.524^{\mathrm{a}}$ & $0.450^{\mathrm{a}}$ & $0.549^{\mathrm{a}}$ & $0.505^{\mathrm{a}}$ & $0.536^{\mathrm{a}}$ & 0.504 & 0.04 & 7.94 \\
\hline $\mathrm{E}$ & $0.250^{\mathrm{a}}$ & $0.269^{\mathrm{a}}$ & $0.230^{\mathrm{a}}$ & $0.329^{\mathrm{a}}$ & $0.363^{\mathrm{a}}$ & $0.321^{\mathrm{a}}$ & 0.295 & 0.05 & 16.95 \\
\hline $\mathrm{K}\left(\mathrm{ex}^{-4}\right)$ & $5.085^{\mathrm{a}}$ & $4.331^{\mathrm{a}}$ & $5.397^{\mathrm{a}}$ & $4.29^{a}$ & $3.370^{\mathrm{a}}$ & $4.208^{\mathrm{a}}$ & 4.446 & 0.7 & 15.74 \\
\hline
\end{tabular}

RE, raw eggs; BE, boiled eggs; SD, Standard deviation; CV, Coefficient of variation

Table 2: Amino-acid profile (g/100g protein) of raw and cooked eggs from three avian species

\begin{tabular}{|l|l|l|l|l|l|l|l|l|l|}
\hline Amino acid & Broiler & Quail & \multicolumn{2}{l|}{ Local chick } & & \\
\hline & RE & BE & RE & BE & RLE & BLE & MEAN & SD & CV \% \\
\hline Glycine & 3.96 & 4.97 & 4.57 & 5.05 & 4.10 & 4.05 & 4.45 & 0.48 & 10.79 \\
\hline Alanine & 5.05 & 6.28 & 5.47 & 5.18 & 5.93 & 5.65 & 5.59 & 0.46 & 8.23 \\
\hline Serine & 4.47 & 3.53 & 3.18 & 3.71 & 4.03 & 3.95 & 3.81 & 0.44 & 11.55 \\
\hline Proline & 2.93 & 2.93 & 2.64 & 2.84 & 3.17 & 2.73 & 2.87 & 0.19 & 6.62 \\
\hline Valine & 4.67 & 4.38 & 3.94 & 3.91 & 4.66 & 4.19 & 4.29 & 0.34 & 7.93 \\
\hline Thrconine & 3.83 & 3.96 & 3.57 & 3.93 & 4.01 & 3.93 & 3.87 & 0.16 & 4.13 \\
\hline Isoleucine & 4.57 & 4.04 & 3.64 & 3.66 & 4.26 & 4.20 & 4.06 & 0.36 & 8.89 \\
\hline Leucine & 6.63 & 8.58 & 7.72 & 8.38 & 9.75 & 8.02 & 8.18 & 1.03 & 12.59 \\
\hline Aspartate & 8.07 & 8.85 & 7.96 & 9.36 & 10.62 & 9.34 & 7.49 & 2.94 & 38.85 \\
\hline Lysine & 8.88 & 3.35 & 7.99 & 3.61 & 10.51 & 8.92 & 7.21 & 3.00 & 41.60 \\
\hline Methionine & 2.89 & 3.29 & 2.96 & 3.04 & 2.54 & 2.64 & 2.89 & 0.27 & 9.34 \\
\hline Glutamate & 14.94 & 14.57 & 13.81 & 14.75 & 14.52 & 14.09 & 14.45 & 0.42 & 2.91 \\
\hline
\end{tabular}


Vitamins, Amino acids, Lipids and Sterols of Eggs from Three different Birds genotypes

\begin{tabular}{|l|l|l|l|l|l|l|l|l|l|}
\hline Phenylalanine & 5.23 & 6.06 & 5.46 & 3.53 & 3.81 & 3.60 & 4.62 & 1.10 & 23.81 \\
\hline Histidine & 2.24 & 2.58 & 2.33 & 2.71 & 3.02 & 2.72 & 2.60 & 2.29 & 11.15 \\
\hline Arginine & 7.47 & 6.33 & 5.70 & 5.41 & 6.45 & 5.72 & 6.18 & 0.75 \\
\hline Thyroisine & 2.28 & 2.87 & 2.60 & 3.11 & 3.34 & 2.78 & 2.83 & 0.38 & 13.43 \\
\hline Tryptophan & 0.66 & 0.69 & 0.82 & 0.79 & 0.74 & 0.66 & 0.73 & 0.07 & 9.59 \\
\hline Cystine & 1.36 & 1.60 & 1.37 & 1.65 & 1.55 & 1.94 & 1.58 & 0.21 & 13.29 \\
\hline T.E.A.A & 34.07 & 42.46 & 38.43 & 33.56 & 43.3 & 38.88 & 38.45 & 4.07 & 10.59 \\
\hline T.N.E.A & 55.53 & 51.92 & 47.30 & 55.28 & 53.71 & 50.15 & 52.32 & 3.20 & 6.12 \\
\hline
\end{tabular}

* Essential fatty acids

Re, raw eggs; BE, Boiled eggs; T.E.N.N, total essential fatty acids; T.N.E.A., total non-essential fatty acids

Table 3: Fatty acid composition (mg/100g) of raw and cooked eggs of three avian species

\begin{tabular}{|c|c|c|c|c|c|c|c|c|c|}
\hline Fatty acids & Broiler & & Quail & & Local chi & & & & \\
\hline & $\mathrm{RE}$ & $\mathrm{Ce}$ & RE & $\mathrm{cE}$ & $\mathrm{RE}$ & $\mathrm{BE}$ & MEAN & S.D & $\mathrm{CV}$ \\
\hline \multicolumn{10}{|l|}{$\mathrm{C}_{2}: 0$} \\
\hline \multicolumn{10}{|l|}{$\mathrm{C}_{3}: 0$} \\
\hline \multicolumn{10}{|l|}{$\mathrm{C}_{4}: 0$} \\
\hline \multicolumn{10}{|l|}{$\mathrm{C}_{5}: 0$} \\
\hline \multicolumn{10}{|l|}{$\mathrm{C}_{6}: 0$} \\
\hline \multicolumn{10}{|l|}{$\mathrm{C}_{8}: 0$} \\
\hline \multicolumn{10}{|l|}{$\mathrm{C}_{10}: 0$} \\
\hline $\mathrm{C}_{12}: 0$ lauric acid & 1.001 & 1.377 & 1.692 & 1.691 & 1.302 & 1.474 & 1.423 & 0.261 & 18.34 \\
\hline $\mathrm{C}_{14}: 0$ myristic acid & 4.786 & 5.207 & 4.561 & 5.054 & 4.248 & 4.561 & 4.736 & 0.354 & 1.14 \\
\hline $\mathrm{C}_{16}: 0$ palmitic acid & 27.470 & 27.460 & 32.776 & 29.284 & 29.801 & 29.544 & 29.389 & 1.954 & 6.65 \\
\hline $\mathrm{C}_{18}: 0$ oleic acid & 8.556 & 9.662 & 7.859 & 7.709 & 8.203 & 10.091 & 8.860 & 0.981 & 11.30 \\
\hline $\mathrm{C}_{20}: 0$ arachidonic & $1.798 \mathrm{e}^{-6}$ & $7.191 \mathrm{e}^{-6}$ & $4.993 \mathrm{e}^{-6}$ & $1.279 \mathrm{e}^{-6}$ & $1.206 \mathrm{e}^{-6}$ & $0.420 \mathrm{e}^{-6}$ & $2.815 \mathrm{e}^{-6}$ & $2.669 \mathrm{e}^{-6}$ & $94.81 \mathrm{e}^{-6}$ \\
\hline $\mathrm{C}_{22}: 0$ behenic acid & $1.659 \mathrm{e}^{-6}$ & $6.635 \mathrm{e}^{-6}$ & $4.607 \mathrm{e}^{-6}$ & $1.180 \mathrm{e}^{-6}$ & $1.113 \mathrm{e}^{-6}$ & $0.920 \mathrm{e}^{-6}$ & $2.765 \mathrm{e}^{-6}$ & $2.311 \mathrm{e}^{-6}$ & $83.58 \mathrm{e}^{-6}$ \\
\hline $\mathrm{C}_{24}: 0$ lignoceric acid & $2.048 \mathrm{e}^{-7}$ & $8.193 \mathrm{e}^{-7}$ & $5.686 \mathrm{e}^{-7}$ & $1.457 \mathrm{e}^{-7}$ & $1.374 \mathrm{e}^{-7}$ & $1.136 \mathrm{e}^{-7}$ & $3.316 \mathrm{e}^{-6}$ & $2.932 \mathrm{e}^{-6}$ & $88.42 \mathrm{e}^{-6}$ \\
\hline SFA (total) & 41.813 & 43.706 & 46.888 & 43.738 & 43.554 & 45.670 & 44.228 & 1.786 & 4.038 \\
\hline $\mathrm{C}_{16}: 1$ (cis-9) & 1.536 & 1.625 & 1.500 & 0.539 & 0.723 & 1.271 & 1.199 & 0.459 & 38.28 \\
\hline $\mathrm{C}_{18}: 1$ cis-6) & 21.545 & 23.998 & 24.438 & 21.022 & 26.597 & 22.616 & 23.369 & 2.067 & 8.85 \\
\hline $\mathrm{C}_{18}: 1$ (cis-9) & 13.949 & 16.325 & 15.414 & 17.816 & 15.935 & 18.680 & 16.353 & 1.697 & 10.38 \\
\hline $\mathrm{C}_{20}: 1$ (cis- 11$)$ & 0.089 & 0.059 & 0.027 & 0.048 & 0.010 & 0.021 & 0.042 & 0.029 & 69.05 \\
\hline $\mathrm{C}_{22}: 1$ (cis-13) & 0.001 & 0.018 & 0.000 & 0.000 & 0.002 & 0.000 & 0.004 & 0.007 & 175.0 \\
\hline $\mathrm{C}_{24}: 1$ (cis-15) & $2.048 \mathrm{e}^{-1}$ & $8.193 \mathrm{e}^{-1}$ & $5.689 \mathrm{e}^{-1}$ & $1.457 \mathrm{e}^{-1}$ & $1.374 \mathrm{e}^{-1}$ & $1.136 \mathrm{e}^{-1}$ & $3.316 \mathrm{e}^{-1}$ & $2.932 \mathrm{e}^{-1}$ & $88.42 \mathrm{e}^{-1}$ \\
\hline MUFA (cis) total & 37.120 & 42.025 & 41.379 & 39.425 & 43.267 & 42.588 & 40.967 & 2.297 & 5.61 \\
\hline $\mathrm{C}_{18}: 1$ (trans-6) & $0.647 \mathrm{e}^{-6}$ & $2.587 \mathrm{e}^{-6}$ & $1.796 \mathrm{e}^{-6}$ & $1.460 \mathrm{e}^{-6}$ & $0.434 \mathrm{e}^{-6}$ & $0.359 \mathrm{e}^{-6}$ & $1.214 \mathrm{e}^{-6}$ & $0.888 \mathrm{e}^{-6}$ & 73.14 \\
\hline $\mathrm{C}_{18}: 1$ (trans-9) & $0.587 \mathrm{e}^{-6}$ & $2.350 \mathrm{e}^{-6}$ & $1.631 \mathrm{e}^{-6}$ & $0.418 \mathrm{e}^{-6}$ & $0.394 \mathrm{e}^{-6}$ & $0.326 \mathrm{e}^{-6}$ & $0.951 \mathrm{e}^{-6}$ & $0.841 \mathrm{e}^{-6}$ & 88.43 \\
\hline MUFA (trans) (total) & $1.234^{-6}$ & $4.937 \mathrm{e}^{-6}$ & $3.427 \mathrm{e}^{-6}$ & $1.878 \mathrm{e}^{-6}$ & $0.828 \mathrm{e}^{-6}$ & $0.677 \mathrm{e}^{-6}$ & $2.163 \mathrm{e}^{-6}$ & $1.687 \mathrm{e}^{-6}$ & 77.99 \\
\hline \multicolumn{10}{|l|}{ PUFA } \\
\hline $\mathrm{C}_{18}: 2(\operatorname{ciss} 9,12)$ & 16.831 & 10.767 & 9.335 & 12.182 & 10.741 & 9.683 & 11.600 & 2.755 & 23.75 \\
\hline $\mathrm{C}_{18}: 3$ ciss $\left.6,9,12\right) 6$ & 0.099 & 0.052 & 0.050 & 0.014 & 0.016 & 0.021 & 0.042 & 0.033 & 78.57 \\
\hline $\mathrm{C}_{18}: 3$ (as $\left.9,12,15\right)$ & 0.002 & 0.003 & 0.002 & 0.005 & 0.001 & 0.001 & 0.002 & 0.001 & 50.0 \\
\hline $\mathrm{E}_{20}: 2(\operatorname{cis} 11,14)$ & $0.255 \mathrm{e}^{-6}$ & $1.018 \mathrm{e}^{-6}$ & $0.707 \mathrm{e}^{-6}$ & $0.181 \mathrm{e}^{-6}$ & $0.171 \mathrm{e}^{-6}$ & $0.141 \mathrm{e}^{-6}$ & $0.412 \mathrm{e}^{-6}$ & $0.364 \mathrm{e}^{-6}$ & 88.35 \\
\hline $\mathrm{C}_{20}: 3($ cis- $8,11,14)$ & $6.884 \mathrm{e}^{-6}$ & $12.000 \mathrm{e}^{-6}$ & $7.220 \mathrm{e}^{-6}$ & $2.339 \mathrm{e}^{-6}$ & $5.547 \mathrm{e}^{-6}$ & $1.671 \mathrm{e}^{-6}$ & $5.944 \mathrm{e}^{-6}$ & $3.758 \mathrm{e}-$ & 63.22 \\
\hline $\mathrm{C}_{20}: 3$ (cis-11,14,17) & $1.100 \mathrm{e}^{-6}$ & $4.399 \mathrm{e}^{-6}$ & $3.054^{-6}$ & $0.782 \mathrm{e}^{-6}$ & $0.788 \mathrm{e}^{-6}$ & $0.610 \mathrm{e}^{-6}$ & $1.789 \mathrm{e}^{-6}$ & $1.568 \mathrm{e}-$ & 87.65 \\
\hline $\mathrm{C}_{20}: 4$ (cis-5,8,11,14) & 1.956 & 1.729 & 1.316 & 3.0382 & 1.250 & 1.314 & 1.767 & 0.682 & 38.60 \\
\hline $\mathrm{C}_{20}: 5($ cis- $5,8,11,14,17)$ & 1.159 & 0.507 & 0.126 & 0.268 & 0.323 & 0.347 & 0.455 & 0.366 & 80.60 \\
\hline $\mathrm{C}_{22}: 2$ (cis-13,16) & 0.014 & 0.018 & 0.031 & 0.020 & 0.009 & 0.002 & 0.013 & 0.007 & 53.85 \\
\hline $\mathrm{C}_{22}: 6($ cis- $4,7,10,13,16,17)$ & 0.414 & 1.192 & 0.889 & 1.040 & 0.522 & 0.688 & 0.791 & 0.303 & 38.31 \\
\hline PUFA total & 20.439 & 14.268 & 12.034 & 16.566 & 12.862 & 12.056 & 14.710 & 3.301 & 22.44 \\
\hline
\end{tabular}

Table 4: Calculated parameters on fatty acids from raw and cooked eggs of three avian species

\begin{tabular}{|l|l|l|l|l|l|l|l|l|l|}
\hline \multicolumn{4}{|l}{} & Broiler & Quail & Local & & \\
\hline Parameter & RE & CE & RE & CE & RE & BE & MEAN & S.D & CV \% \\
\hline SFA & 41.813 & 43.706 & 46.898 & 43.738 & 43.554 & 45.670 & 44.228 & 1.786 & 4.078 \\
\hline MUFA (as) & 37.120 & 42.025 & 41.379 & 39.425 & 43.267 & 42.588 & 40.967 & 2.297 & 5.61 \\
\hline MUFA (tras) & $1.234 \mathrm{e}^{-6}$ & $4.937 \mathrm{e}^{-6}$ & $3.427 \mathrm{e}^{-6}$ & $1.878 \mathrm{e}^{-6}$ & $0.828 \mathrm{e}^{-6}$ & $0.677 \mathrm{e}^{-6}$ & $2.163 \mathrm{e}^{-6}$ & $1.687 \mathrm{e}$ & 77.99 \\
\hline MUFA total & 37.120 & 42.025 & 41.379 & 39.425 & 43.267 & 42.588 & 40.967 & 2.297 & 5.61 \\
\hline PUFA & 20.474 & 14.268 & 12.034 & 16.566 & 12.862 & 12.056 & 14.710 & 3.301 & 22.44 \\
\hline AA/DGLA & 0.326 & 0.288 & 0.219 & 0.506 & 0.208 & 0.219 & 0.294 & 0.114 & 38.76 \\
\hline EPA/DHA & 2.829 & 0.428 & 0.015 & 0.260 & 0.615 & 0.507 & 0.776 & 1.028 & 132.47 \\
\hline LA/ALA & 8415.5 & 3589.0 & 4667.5 & 2436.4 & 10741.0 & 9683.0 & 6588.7 & 3466.5 & 52.61 \\
\hline $\mathrm{n}-6$ & 20.045 & 13.055 & 10.827 & 15.501 & 12.330 & 11.365 & 2.001 & 0.818 & 40.88 \\
\hline $\mathrm{n}-3$ & 1.575 & 1.702 & 1.017 & 1.308 & 0.846 & 1.036 & 1.247 & 0.340 & 27.27 \\
\hline $\mathrm{n}-6 / \mathrm{n}-3$ & 12.727 & 7.670 & 10.647 & 11.851 & 14.574 & 10.970 & 1.589 & 0.404 & 25.43 \\
\hline PUFA/SFA & 0.490 & 0.320 & 0.257 & 0.379 & 0.295 & 0.264 & 0.334 & 0.088 & 26.35 \\
\hline MUFA/SFA & 0.888 & 0.962 & 0.883 & 0.901 & 0.993 & 0.933 & 0.927 & 0.044 & 4.75 \\
\hline EPSI & 0.552 & 0.340 & 0.291 & 0.420 & 0.297 & 0.283 & 0.364 & 0.105 & 28.85 \\
\hline
\end{tabular}

RE, raw eggs; CE, cooked eggs 
Vitamins, Amino acids, Lipids and Sterols of Eggs from Three different Birds genotypes

Table 5: Sterol levels $(\mathrm{mg} / 100 \mathrm{~g})$ ofraw and cooked parts of eggs from three avian species

\begin{tabular}{|c|c|c|c|c|c|c|c|c|c|}
\hline \multirow[b]{2}{*}{ Sterols } & \multicolumn{2}{|c|}{ Broiler } & \multicolumn{2}{|l|}{ Quail } & \multicolumn{2}{|c|}{ Local chick } & & & \\
\hline & $\mathrm{RE}$ & $\mathrm{BE}$ & $\mathrm{RE}$ & $\mathrm{BE}$ & $\mathrm{RE}$ & $\mathrm{BE}$ & MEAN & S.D & CV \% \\
\hline Cholesterol & 269.9 & 321.1 & 279.2 & 231.0 & 357.2 & 260.0 & 286.4 & 45.40 & 15.85 \\
\hline Cholestanol & 0.002 & 0.002 & 0.002 & 0.002 & 0.002 & 0.002 & 0.002 & 0.00 & 0.00 \\
\hline Ergosterol & 0.046 & 0.046 & 0.046 & 0.046 & 0.046 & 0.046 & 0.046 & 0.00 & 0.00 \\
\hline Campesterol & 0.104 & 0.081 & 0.113 & 0.171 & 0.103 & 0.092 & 0.111 & 0.03 & 27.03 \\
\hline Stigmasterol & 0.174 & 0.122 & 0.193 & 0.220 & 0.201 & 0.148 & 0.176 & 0.04 & 22.73 \\
\hline Savenasterol & 0.011 & 0.022 & 0.000 & 0.019 & 1.001 & 0.008 & 0.177 & 0.40 & 225.98 \\
\hline Sitosterol & 0.453 & 0.442 & 0.454 & 0.458 & 0.384 & 0.353 & 0.424 & 0.04 & 9.43 \\
\hline
\end{tabular}

RE, raw eggs; BE, boiled eggs; S.D, Standard deviation; CV, Coefficient of variation

\section{References}

[1]. US Department of Agriculture, Food and NutritionS Service. Dietary Guidelines for Americans,Washington, D.C. 2005.http://www.mypyraid.gov//guiglines/index_print.html Accessed $10^{\text {th }}$ June 2012

[2]. A.V, Vaclavikand W.E.Chistian Essentials of Food Science .Springer Science Bussiness Media LLC New York,2008 205-230

[3]. T,Triziska Procecessing of eggs in egg science Ed .University of Agiculture in Wroclaw (Poland) 2000 291-401

[4]. E. F,Gueye . Production and consumption trend in Africa. World Poultry., 2003 19: 12-14

[5]. A.Genchev. Quality and Composition of Japanese quail Egg (Coturnix Cournix Japonica) Trakia Journal of Sciences 10 (2), 2012, 91-101

[6]. AOAC, Official methods of Analysis of AOAC.International. 18 ${ }^{\text {th }}$ edition.lnc. Maryland 20877-2417. USA.2005, 2-74

[7]. J.W.DeVeries, Concurrent analysis of Vitamin A and Vitamin E by reversed phase high performance liquid chromatography analysis of food and beverage 2005, 447-485

[8]. T.Cserhati and E.Forgacs, Chromatography in Food Science and Technology. Technomic publishing Co. Lancaster, USA. 1999, 158-298.

[9]. R.A.Oloyo, Fundamental of Research methodology for Social and Applied Sciences ROA Educational Press, Nigeria,2001

[10]. L.Bashir, P.C.Ossai. O.K.Shittu, A.N.Abubakar and T.Caleb, Comparison of the Nutritive Value of Egg yolk and Egg albumen for Domestic Chicken, Guinea fowl and Hybrid Chicken. American Journal of Experimental Agriculture 6(5) 2015, 310-316

[11]. E.J.Konings, Committee on Food Nutrition. Water Soluble Vitamins. Journal of AOAC International 89(1) 2006,285-288

[12]. I.Ahma, T.Mirza, K.Qadeer, U.Nazim, and F.HVaid,. Vitamin B6 Deficiency Diseases and methods of Analysis .Pakistan Journal of Pharmaceutical Science 26(5) 2013,1057-1069

[13]. C.L.Taiylor, K.Y.Patterson, J.M.Roseland,S.A.Wise,J.M.Merkel,P.R.Pehsson,andE.AYetley,Including food 25-hydrovitamin D intake estimates may reduce the discrepancy between dietary and serum measures of Vitamin D statu, Journal of Nutrition 144, 2014, 654-659

[14]. T.Tanasorrn, W.Tungjaroenchai, and W.Siriwon,.Nutrient Benefits of Quail Eggs, International Journal of Science and Research Publication, 3 (5) 2013, 2225-3153

[15]. H.Augustine, K.Griesjean, Q.Chen and D.E,Featherson ,Non Vesicular release of glutamate by XCT transporters suppresses glutamate receptor clustering lnvivo. Journal of Neuroscience 27(1) 2007,111-123

[16]. I.O.Dudusola, Comparative evaluation of internal and external qualities of eggs from quail and guinea fowl, International Research Journal of Plant Science 1(5) 2010, 112-115

[17]. P.Garlic,(2005).The role of leucine in the regulation of protein Metabolism .Journal of Nutrition 135 2005,1553-1556

[18]. P.Evenepoel, B.Geypens, A.Luypaerts, M.Hiele, Y.Ghoos and P.Rutgeerts, Digestibility of Cooked and Raw Egg Protein in Humans as Assessed by Stable Isotope Techniques, The Journal of Nutrition, 128 (10), 1998, 1716-1722

[19]. M.D.Baucells, N.Crespo, A.C,Barroela, S,Lopez-Ferrer and M.A,Grashornt,M.A, incorporation of Different Polyunsaturated fatty acids Eggs. Poultry Science 78, 1977, 52-59.

[20]. W.N.Wassef, The Thermal degradation of lipids. Journal .Agricultural Food Chemistry 17(1) 1969, 18-21S

[21]. Adeyeye, E.I and Aye,P.A (2013) Lipid Composition of three Organs of Hippo tragus equines (Roan Antelop) Elixir Food Science 58:14891-14901.

[22]. CDC..Nutrition for everyone:Basics: Trans fat. 2012. http://www.cdc.gov/nutrition/everyone/basics/fat/transfat.html Accessed 20 ${ }^{\text {th }}$ March 2012

[23]. Barham,J.B.,Edens,M.B.Fonteh,A.N.,Johnson,M.M.,Easter,C and F.M,Chilton,Addition of eicosatetranoic to gamma linolenic acid supplement diet prevents serum arachidonic acid accumulationin humans. Journal of NutrItion 130 2000, $1925-1931$.

[24]. P.Benatti, G.Peluso, R.Nicolai andM.Calvani, Polysaturated fattyacid,biochemical,Nutritional and Epigenic properties.Journal of the American college of Nutrition 23(4) 2004, 281-302

[25]. H.Bruce, Perspective on DHA and AA for infant Feeding and Health from the DHA/EPA Omega -3 institute :A Special Report. July 28,2016

[26]. W.Stonehouse,C.AConion,J.Podd,S.RHill,A.MMinihane,I.CHaskeandD.Kenn, DHA supplementation improved the memory and reaction time in healthy young adults: a randomized controlled trial. American Clinical Nutrition 97(5) 2013,1134-1143

[27]. W.E.Vanek,Connor (2007) :Do n-3 fatty acid prevent Osteoporosis? American Journal of Clinical Nutrition, 85(3) 2007,647-648

[28]. N.D.Jeehangir, D.E Newby,and A.D.Flapan, Omega 3 Fatty acids and cardiovascular disease-fishing for natural treatment. Agency for Healthcare and Research, Clinical Review BMJ 2004

[29]. B.S,Reeddy, Amount and Type of dietary fat and colon cancer: Animal Model Studies .Progress Clinical Biological Research 222, $1986,295-309$

[30]. K.Premavalli,A.V.Omprakash,R.Ezhilvalavan,M.Babu,R.PSenthil,andA.Natanrajan,A(2015). Comparative egg yolk fatty acid profile of a Seal and Guinea fowl. Journal of Veterinary Science Technology 6, 2015,6-15

[31]. G.Honatra.Dietary fat and arterial thrombosis, Journal of Thrombosis and Haemostatis 2,1974 21-52

[32]. J.Renee.Does fast food cause Heart Diseases: $15^{\mathrm{TH}}$ May 2015.http://www.livestrong,com/article/26855.Acessed $11^{\text {th }}$ January 2017 